\title{
Strategi Komisi Pemilihan Umum Provinsi Sumatera Barat Dalam Menghadapi Penundaan Persiapan Tahapan Pilkada Serentak Tahun 2020 Akibat Covid-19
}

\author{
${ }^{1}$ Riko Riyanda, ${ }^{2}$ Ilham \\ 12 Program Studi Ilmu Politik, Fakultas Ilmu Sosial Dan Ilmu Politik \\ Univeristas Muhammadiyah Sumatera Barat \\ e-mail: riyanda.fisip@gmail.com
}

\begin{abstract}
Abstrak
Pelaksanaan pilkada serentak pada situasi pandemi akan manyangkut langsung dengan persoalan keselamatan dan kesehatan jiwa pemilih. KPU Provinsi Sumatera Barat disamping mewujudkan pilkada yang demokratis disaat yang bersamaan juga diharapkan bisa berjalan dengan aman, lancar dan tidak ada korban satu apapun. Penelitian ini bertujuan untuk mendeskripsikan dan mengidentifikasi strategi KPU Provinsi Sumatera Barat dalam menghadapi penundaan pilkada serentak tahun 2020 akibat Covid 19. Metode pengambilan data dilakukan dengan cara wawancara, observasi dan dokumentasi, teknik pemilihan informan dengan purposive sampling. Adapun hasil penelitian ini strategi KPU Provinsi Sumatera Barat dalam menghadapi penundaan pilkada serentak akibat masa pandemi Covid 19 adalah: pertama, meninjau secara kesinambungan perkembangan Peta Sebaran Covid 19 Di Sumatera Barat, kedua, memastikan semua tahapan pilkada harus mematuhi protokol kesehatan, ketiga, mengoptimalkan aturan kampanye di media masa selama pandemi Covid 19 dan Keempat, melibatkan seluruh komponen masyarakat untuk meningkatkan partisipasi pemilih.
\end{abstract}

Kata Kunci: Strategi, KPU Provinsi Sumatera Barat, Virus Covid-19

\begin{abstract}
With unusual conditions, there must be a strategy taken by the Provincial KPU in dealing with the impact sand consequences of the dangers of Covid 19. Situation pandemic in the implementation of simultaneous regional elections will be directly related to issues of safety and mental health of the community. In addition to realizing democratic election sat the sametime, it is hoped that the simultaneous regional elections can run safely, smoothly and without any casualties. This study aims to describe and identify the strategy of the West Sumatra Provincial Election Commission in dealing with simultaneous regional election delays in 2020 due to Covid 19. Method of collecting data was done by interview, observation and documentation. Technique of selecting informant was purposive sampling. The result sof this study include the strategies of the West Sumatra Provincial Election Commission in Facing Simultaneous Regional Election Delays in the Covid 19 Pandemic, namely: first, reviewing the development of the Covid 19 Distribution Map in West Sumatra, second, ensuring all stages of the election must comply with health protocols, third, optimal campaign rules in mass media during the Covid 19 and Fourth pandemic, involving all component sof society to increase voter participation.
\end{abstract}

Keywords: Strategy, West Sumatra Provincial ElectionCommission, Covid-19 


\section{PENDAHULUAN}

Pemilihan kepala daerah langsung atau pilkada menjadi isu yang sangat hangat sekarang ini. Kepala daerah sangatlah strategis dan dapat dikatakan sebagai "primus imterpares" untuk majunya suatu daerah (Djormansyah Djohan, 2005: 15).

Memasuki tahun 2020, sesuai dengan keputusan Komisi Pemilihan umum (KPU), akan digelar pilkada serentak pada Rabu, 23 Sepetember 2020. Sebanyak 270 daerah akan menggelar pemilihan kepala daerah (pilkada) secara serentak pada 2020. Dari 270 daerah yang menggelar pilkada serentak, sembilan di antaranya merupakan provinsi, sisanya, 37 kota dan 224 kabupaten juga menggelar pilkada serentak 2020. Ada sejumlah tahapan yang harus dilalui dalam pilkada serentak 2020. KPU telah merilis jadwal dan tahapan yang telah ditetapkan dalam Peraturan Komisi Pemilhan Umum (PKPU) nomor 15 tahun 2019.

Adanya wabah pendemi corona ini telah membuat jadwal tahapan pelaksanaan pilkada tahun 2020 menjadi tertunda. Payung hukum yang semula sudah disepakati oleh pemerintah dan DPR (UU Nomor 10 Tahun 2016 tentang pilkada), kemudian ditunda dengan alasan negara dalam keadaan darurat. Penundaan tersebut pada akhirnya ditetapkan oleh pemerintah dan DPR pada tanggal 9 Desember 2020 lewat payung hukum Perpu No 2 Tahun 2020 Tentang perubahan ketiga atas undang-undang Nomor 1 Tahun 2015 tentang Penetapan Peraturan Pemerintah Pengganti Undang-Undang Nomor 1 Tahun 2014 tentang Pemilihan Gubernur, Bupati, dan Wali kota Menjadi Undang-Undang. Penundaan pelaksanaan pilkada 2020 tentu mempengaruhi persipan dari KPU Provinsi Sumatera Barat, apalagi pada saat merebaknya pandemi virus korona.

Menghadapi penundaan ini, perencanaan tahapan pilkada oleh KPU jelas akan berubah dari segi waktunya. Persoalanya negara dihadapkan masih berada ketidak pastian kapan pandemi covid 19 ini akan segara berakhir.

Wabah Covid 19 ini bisa dijadikan evaluasi untuk pembenahan bagi penyelenggara pilkada dan buat partai politik agar mempersiapkan strategi, agar meminimalisir terjadinya masalah dalam pelaksanan tahapan pilkada seerentak ini, tidak terkecuali Provinsi Sumatera Barat yang juga kena dampak dari kebijakan secara nasional akibat dari penundaan pilkada serentak 2020.

\section{Teori Strategi}

Strategi juga dikenal dalam proses penyelenggaraan pembangunan yang biasanya dilakukan oleh birokrasi pemerintah, baik di tingkat pusat maupun di tingkat daerah. Strategi ini bertujuan untuk memaksimalkan hasil yang dicapai suatu program pembangunan, sebagai akibat keterbatasan sumberdaya yang ada, dengan cara mengoptimalkan dan mengalokasikan secara tepat sumberdaya tersebut. (Tangkilisan, 2009: 403).

Sementara itu, Thompson dalam (Oliver, 2007) mendefisinikan strategi sebagai cara untuk mencapai sebuah hasil akhir. Hasil akhir menyangkut tujuan dan sasaran organisasi. Ada strategi yang luas untuk keseluruhan organisasi dan sstrategi kompetitif untuk masing-masing aktivitas. Sementara itu, strategi fungsional mendorong secara langsung strategi kompetitif. Bennett dalam Oliver mengambarkan strategi sebagai arah yang diplih organisasi untuk diikuti dalam mencapai misinya.

Menurut Dess dan Lumpkin terdapat elemen utama yang merupakan jantung manajemen strategi, dalam manajemen strategi memerlukan 3 proses yang berkelanjutan yaitu: analisis, keputusan, dan aksi. Elemen ini mengarahkan organisasi dalam mencapai tujuan dan sasarannya, serta melibatkan semua stakeholders dalam pengambilan keputusan (Nur Hidayah dkk, 2014: 3). 


\section{Teori Demokrasi Melalui Pilkada Langsung}

Dimensi dari demokrasi adalah melakukan pemilu di tingkat nasional dan pilkada di tingkat lokal (daerah). Pada prinsipnya pemilu ataupun pilkada langsung adalah arena untuk mengekspresika kebebasan rakyat dalam memilih dan menseleksi pemimpin yang dikehendaki oleh rakyatnya. Partai politik merupakan sarana partisipasi politik masyarakat dalam mengembangkan kehudidupan demokrasi, sedangkan KPUD merupakan penyelenggara pemilu kada yang harus melaksanakan tugas dan kewajibannya dengan berasaskan Jurdil dan Luber. (Debora Sanur Lindawati, 2013: 289).

Demokrasi melalui mekanisme pemilihan langsung pada hakekatnya adalah membuka akses seluas mungkin bagi partisipasi masyarakat dalam menentukan pemimpin pemerintahan. Bahkan, sebagaimana dikatakan Jhon Stuart Mill, setiap minoritas dihargai dalam partisipasi demokrasi. Lebih dari itu, setiap individu yang terlibat dalam proses demokrasi sekecil apapun harus turut bertanggungjawab.(Robert Dahl, 2001:34).

Salah satu bentuk praktek demokrasi yang sekarang ini dijalankan oleh bangsa Indonesia adalah pemilihan kepala daerah (Pilkada, red). Sebagaimana telah diamanatkan dalam Pasal 18 ayat (4) UUD 1945, Gubernur, Bupati dan Wali Kota, masing-masing sebagai kepala pemerintahan daerah provinsi, kabupaten, dan kota dipilih secara demokratis. Hal ini juga dipertegas dalam UU No 32 Tahun 2004 tentang Pemerintah Daerah yang didalamnya mengatur bahwa kepala daerah dipilih secara langsung. Pilkada langsung merupakan jawaban atas tuntutan aspirasi rakyat karena pemilihan presiden dan wakil presiden, DPR, DPD telah dilakukan secara langsung sebelumnya. (Amiruddin dan A Azaini Bisri, 2006:66)

Apabila dicermati, ketentuan Pasal 18 ayat (4) UUD 1945 tersebut tidak menegaskan keharusan bahwa Gubernur, Bupati, dan Walikota harus dipilih melalui suatu pemilihan yang dilaksanakan secara langsung. Akan tetapi, menurut Rozali Abdullah, oleh karena daerah merupakan bagian yang tak terpisahkan dari negara Republik Indonesia, maka dalam melakuka pemilihan kepala daerah dan wakil kepala daerah seharusnya sinkron dengan pemilihan presiden dan wakil presiden, yaitu melalui pemilihan langsung. (Nopyandri, 2011:2)

Hadirnya pemilukada paling tidak didorong oleh lima hal penting yaitu, pertama, respon terhadap tuntutan aspirasi masyarakat yang semakin luas akibat tingginya dominasi partai lewat kekuasaan legislatif lokal. Kedua, lahirnya perubahan pada level konstitusi mendorong dilakukannya perubahan secara normatif terhadap semua pengaturan soal pemilukada. Ketiga, pemilukada merupakan proses pembelajaran demokrasi pada tingkat lokal. Lahirnya leadership memberi harapan bagi terciptanya tanggung jawab yang tinggi melalui pendekatan kearifan lokal. Keempat, pemilukada sebagai spirit dalam penyelenggaraan otonomi, dimana aktualisasi hak-hak otonomi daerah diantaranya dapat memilih dan dipilih secara langsung. Kelima, pemilukada sebagai proses pendidikan kepemimpinan bangsa di setiap strata dapat menciptakan kepemimpinan yang kuat. (Labolo, 2015: 1-2)

\section{METODE}

Penelitian ini menggunakan deskriptif kualitatif. Penelitian deskriptif kualitatif adalah salah satu metode untuk mendapatkan kebenaran dan tergolong sebagai penelitian ilmiah yang dibangun atas dasar teori-teori yang berkembang dari penelitian dan terkontrol atas dasar empirik. Metode penelitian yang dilakukan adalah deskriptif dengan pendekatan penelitian

kualitatif yaitu menggambarkan atau melukiskan keadaan subjek dan objek, baik seseorang, lembaga dan masyarakat, dan lain sebagainya. Serta didasarkan atas hasil observasi yang dilaksanakan serta memberikan argumentasi terhadap apa yang ditemukan dilapangan dan dihubungkan dengan konsep teori yang relevan. (Sari, 2016). Dalam penelitian ini, fokus penelitian diarahkan pada strategi KPU Provinsi 
Sumatera Barat dalam menghadapi penundaan persiapan tahapan pilkada serentak tahun 2020 akibat Covid 19. Lokasi penelitian di kantor KPU Provinsi Sumatera Barat dengan alamat J1.Pramuka Raya, Nomor 9, Lolong Belanti, Kecamatan Padang Utara, Kota Padang, Sumatera Barat.

\section{HASIL DAN PEMBAHASAN}

Berdasarkan hasil temuan data peneliti di lapangan bahwa strategi KPU Provinsi Sumatera Barat Dalam Menghadapi Penundaan Pilkada Serentak Masa Pandemi Covid 19 yaitu:

\section{Meninjau Update (terkini) perkembangan Peta Sebaran Covid 19 Di Sumatera Barat}

Menyelenggarakan pilkada di masa pendemi, penting untuk meninjau terus upadate berbasis data perkembangan covid 19. Ada empat yang terus ditinjau terhadap data perkembangan Covid 19, pertama tingkat pertambahan penderita, kedua tingkat kematian, ketiga tingkat penyembuhan, keempat sebaran Covid 19. Empat indikator tersebut dapat dijadikan acuan dalam penyelenggaraan pilkada di masa pandemi Covid 19.

Dari ke empat indikator itu, dapat diambil langkah-langkah strategis terkait keberlanjutan pilkada. Oleh karena itu, data yang selalu update dan dapat dipercaya kevalidannya diperlukan sekali untuk mengambil langkah strategis berikutnya terkait dengan keberlanjutan pilkada. Bagi penyelenggara berkewajiban mewujudkan pilkada yang demokratis dapat tercapai disamping kesehatan dan keselamatan pemilih dapat terlindungi.

Melansir data Kementrian Kesehatan Republik Indonesia:

\section{Gambar 1. Peta Sebaran Kasus Per Provinsi}

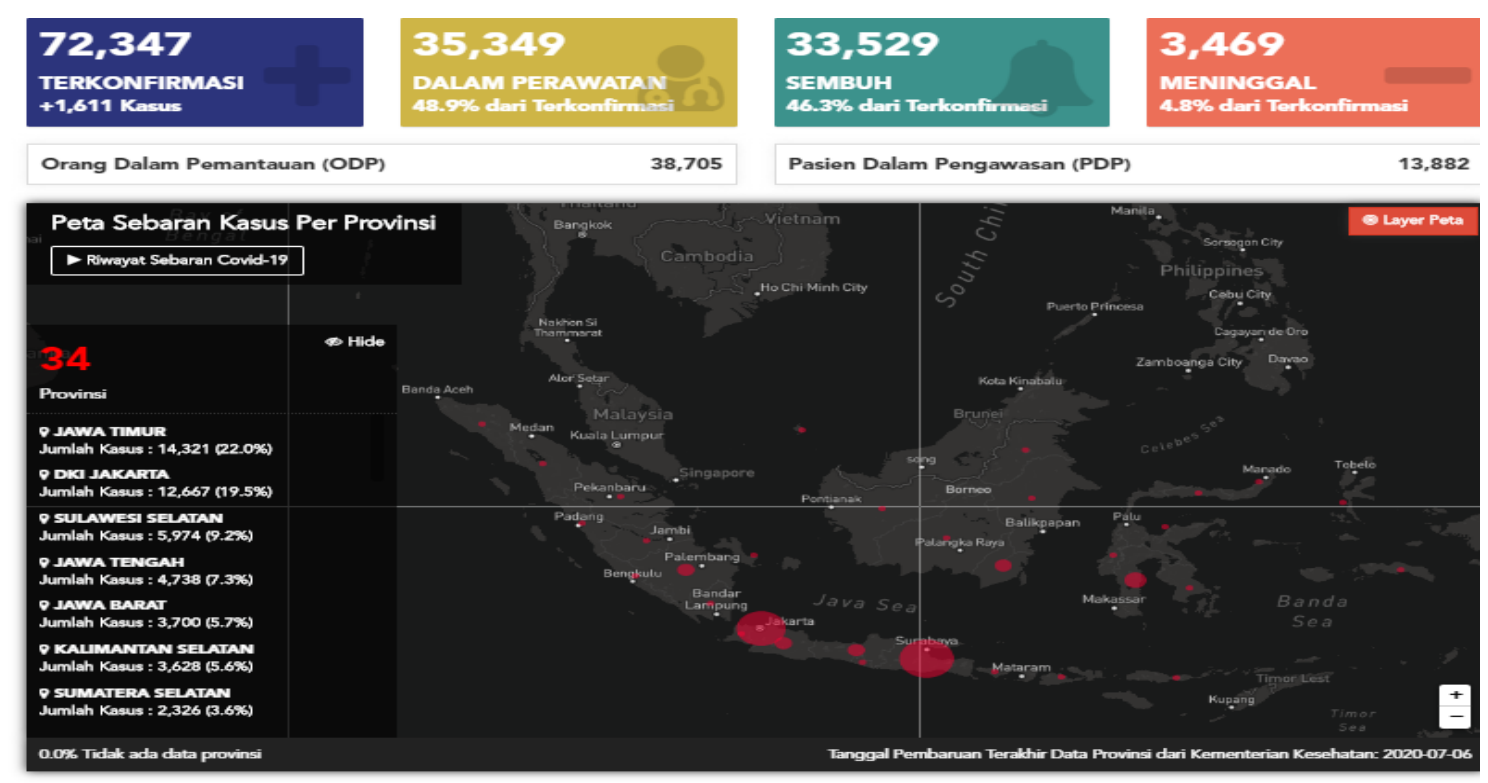

Sumber: Kementerian Kesehatan, 2020

Sementara itu, dari pantauan kasus per-provinsi di Indonesia, Provinsi Sumatera Barat merupakan provinsi yang terendah kasus terkonfimasi wabah Covid 19. Dari data Kementerian Kesehatan, terlihat dari data diatas, data yang meninggal, sembuh, dan dalam perawatan/isolasi mandiri, Provinsi Sumatera Barat merupakan provinsi yang paling tinggi tingkat kesembuhannya terhadap kasus terkonfirmasi Covid 19. Situasi ini menandakan bahwa ada keberhasilan Provinsi Sumatera Barat dalam upaya menangani 
wabah covid-19. Sedangkan kasus terkonfirmasi perawatan/isolasi mandiri yang tertinggi adalah Provinsi Jawa Timur, dan diikuti Provinsi DKI Jakarta. Datanya dapat dilihat dari gambar di bawah ini:

Gambar 2. Kasus Per Provinsi

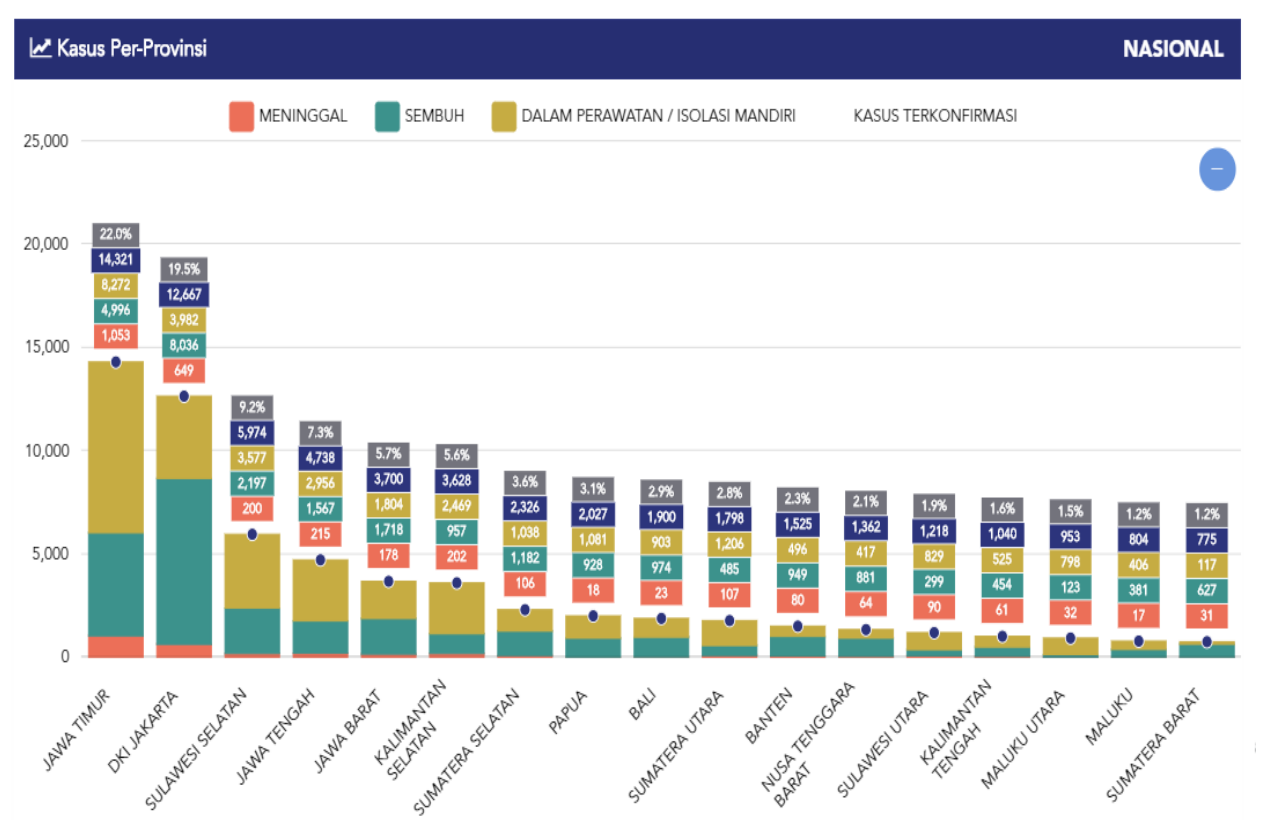

Sumber: Kementerian Kesehatan, 2020

Peta perkembangan sebaran covid 19 di Sumatera Barat ini menjadi penting sebab, langkah strategi apa yang akan diambil tergantung dari perkembangan sebaran covid 19 ini. Yang terpenting lagi adalah bagaimana pelaksanaan sosialisasi pelaksanaan pemilu di tengah pandemi terkait dengan informasi aturan/protocol kesehatan sampai ke masyarakat.

Sosialiasasi pelaksanaan pemilu di tengah pandemi ini ditentukan oleh kesiapan KPU Provinsi Sumatera Barat sebagai penyelenggara. KPU Provinsi Sumatera Barat selama ini sangat intens mensosialisasikan pilkada di tengah pandemi dengan mengimbau masyarakat untuk mematuhi aturan/protokol kesehatan, dimulai dati tahap persiapan sampai sampai hari pemungutan suara. Proses sosialisasi itu dengan menggunakan sarana instagram, youtube, facebook, option dan wasttapp.

\section{Memastikan Semua Tahapan Pilkada Harus Mematuhi Protokol Kesehatan}

Tahapan pilkada serentak di tahun 2020 akan dilalui dengan protokol kesehatan yang ketat, standar protokol kesehatan bertujuan untuk menyelamatkan keselamatan warga dan memprioritaskan perlindungan kesehatan. Pemberlakuan protokol tersebut mulai dilaksanakan sejak tahapan lanjutan, yakni pembentukan ad hoc Petugas Pemutakhiran Data Pemilih (PPDP) dan verifikasi dukungan calon perseorangan.

KPU telah merancang Peraturan KPU tentang penyelanggaraan pilkada 2020 di tengah pandemi Covid 19. Protokol ksehatan itu berlaku bagi para petugas penyelenggara seperti menggunakan pakaian alat pelindung diri (APD), masker, face shiled, dan hand sanitizer, kemudian dalam pelaksanaan tahapannya seperti menjaga jarak dan meminimalisir kerumunan.

Di dalam Peraturan Komisi Pemilihan Umum Republik Nomor 6 Tahun 2020 Tentang pelaksanaan Pemilihan Gubernur dan Wakil Gubernur, Bupati dan Wakil Bupati, Dan/Atau Wali Kota Dan Wakil Wali Kota Serentak Lanjutan Dalam Kondisi Bencana Non Alam Corona Virus Disease 2019 (Covid-19) dalam pasal 5 ayat (1) Pemilihan Serentak Lanjutan dilaksanakan dengan protokol kesehatan 
pencegahan dan pengendalian Corona Virus Disease 2019 (COVID-19) dengan memperhatikan kesehatan dan keselamatan penyelenggara Pemilihan, peserta pemilihan, pemilih, dan seluruh pihak yang terlibat dalam penyelenggaraan Pemilihan. Aturan protokol kesehatan Covid 19 ini dapat lihat dari gambar berikut ini:

\section{Gambar 3. Protokol Kesehatan Covid-19}

\section{Protokol Kesehatan Covid-19}

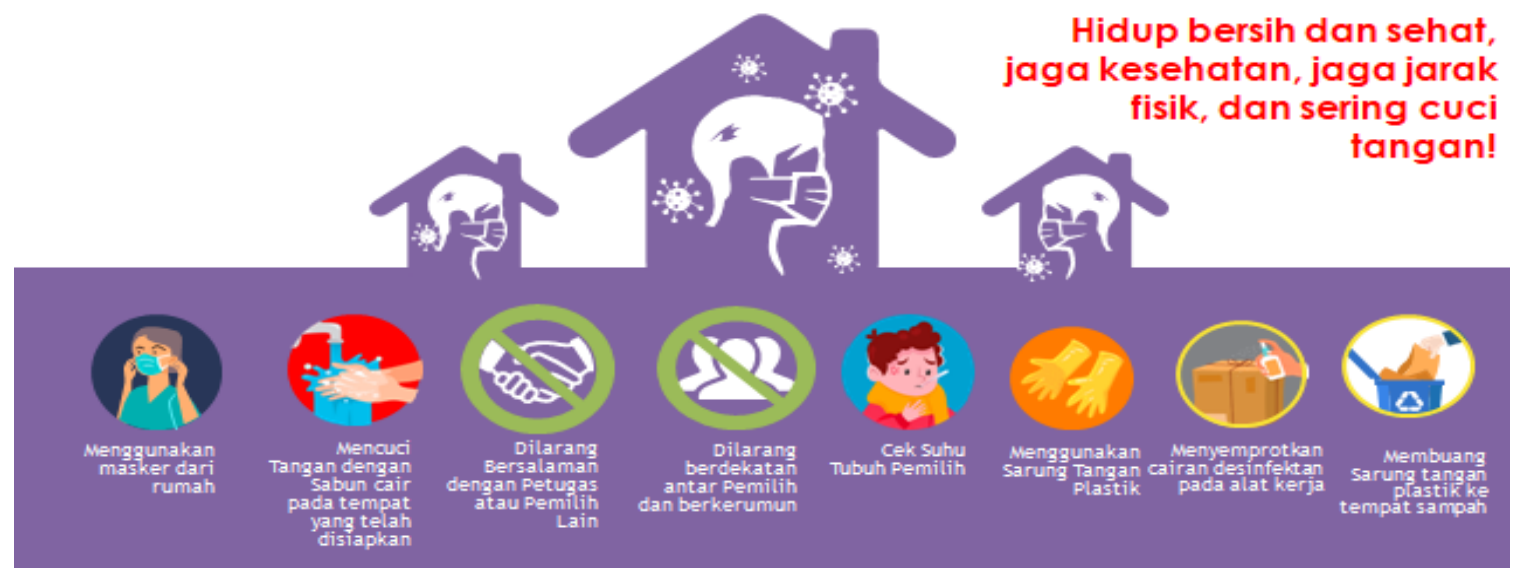

Dengan memastikan mamatuhi aturan protokol kesehatan adalah langkah untuk memutus mata rantai penyebaran wabah Covid 19. Kondisi pandemi memang tugas berat bagi KPU sebagai penyelenggara. Dapat dipastikan pilkada serentak dengan aturan protokol kesehatan ini memang rumit, sulit dan menghabsikan anggaran yang besar, penyelenggaraan tahapan pilkada saat pandemipun rentan bagi pemilih apalagi bagi penyelenggara pilkada.

Pada situasi tahapan pemilihan, penyelenggara pemilu sebagaimana yang diatur dalam UU Nomor 10 Tahun 2016 Perubahan Kedua Atas Undang-Undang Nomor 1 Tahun 2015 Tentang Penetapan Peraturan Pemerintah Pengganti Undang-Undang Nomor 12014 Tentang Pemilihan Gubernur, Bupati dan Walikota menjadi Undang-Undan, verifikasi yang diatur dalam pasal 48 UU pilkada memuat tentang proses verifikasi KTP sebagai syarat untuk calon independen.

Salah satu yang mendesak untuk tahapan pilkada ini adalah mempersiapkan tenaga verifikator untuk turun ke lapangan. Sehingga kegiatan ini dikemas dalam bentuk bimbingan teknis selama 2 hari (21-22 Juni). Karena masih berada dalam situasi pandemi Covid-19, maka beberapa aturan protokol kesehatan diupayakan untuk dipenuhi sesuai dengan anjuran pemerintah.

Begitu juga saat turun lapangan nanti, tenaga verfak akan dilengkapi alat pelindung diri. Minimal menggunakan masker, face shield, hand sanitizer, sering cuci tangan, memakai sarung tangan dan lainnya. Saat bimtek perserta diatur jarak duduk, dibatasi jumlahnya. Lalu menggunakan masker dan harus cuci tangan dulu sesuai protokol kesehatan.

Tantangan pada tahapan verifikasi faktual ini lebih kepada kepatuhan dan pemahaman PPS/petugas verifikasi terkait pelaksanaan tugas di lapangan. Adanya Covid 19 membuat masyarakat belum terbiasa dengan penyelenggara yang memakai Alat Pelindung Diri (APD) lengkap dan kadang enggan menerima petugas verifikasi yang datang ke rumahnya.

Kesuksesan dalam sebuah pemilu sangat ditentukann oleh penyelenggara pemilu. Kesuksesan itu diukur dengan terselenggaranya pemilu/pemilihan yang demokratis. Tahap verfikasi merupakan salah 
satu tahap yang menentukan terhadap ukuran sukses tidaknya pilkada di Sumatera Barat yang akan berlangsung 9 Desember 2020 nanti.

Tahapan yang juga sangat penting dan krusial adalah tahap pemutakhiran data, penyusunan daftar pemilih dan merupakan salah satu tahapan yang strategis bagi terselenggaranya pemilihan kepala daerah. Penyelenggara pemilu memastikan setiap warga negara terdaftar sebagai pemilihan tanpa diskriminasi. Jaminan pemilihan pemilih tanpa dikriminasi termasuk akses pemilih untuk terdaftar dan mengetahui data pemilih (dirinya) secara mudah, termasuk untuk memperbaiki data dirinya apabila terdapat kekeliruan atau perubahan elemen data.

Pemutakhiran data dan penyusunan daftar pemillih menentukan bagi tahapan pemilihan selanjutnya. Mulai dari penentuan jumlah TPS, alokasi logisitik, pola sosialisasi pemilu, kampanye, rekapitulasi hasil suara. Dan lain sebagainya. Jika hasil pemutakhiran data dan penyusunan daftar pemilih bermasalah atau tidak valid, dapat dipastikan tahapan pemilihan selanjutnya juga akan sangat terganggu.

Beberapa langkah penyelenggara pilkada dengan mengikuti rangkaian sebagai berikut:

1. Wajib melakukan Rapid Test

- KPU Provinsi dan KPU Kabupaten/Kotadi di semua wilayah Sumatera Barat dilakukan Rapid Test sebanyak 3 kali selama pelaksanaan tahapan;

- PPK dan PPS dilakukan Rapid Test sebanyak 2 kali selama masa kerja;

- PPDP dan KPPS dilakukan Rapid Test sebanyak 1 kali selama masa kerja;

2. Pemberian Vitamin Daya Tahan Tubuh

- KPU Provinsi dan KPU Kabupaten/Kota di semua wilayah Sumatera Barat selama pelaksanaan tahapan;

- PPK, PPS PPDP dan KPPS mendapatkan vitamin daya tahan tubuh selama masa kerja;

3. Pemeriksaan jika terjadi gejala demam dan batuk dan lain sebainya

4. Melakukan pemeriksaan Suhu Tubuh pada seluruh jajaran

- KPU Provinsi dan KPU Kabupaten/Kota di wilayah Sumatera Barat selama pelaksanaan tahapan;

- PPK, PPS, PPDP dan KPPS sebelum dan sesudah menjalankan tugas;

5. Pemberian Perlengkapan Alat Pelindung Diri

- Seluruh Penyelenggara Pemilihan dilengkapi dengan Alat Pelindung Diri sesuai dengan standar Kesehatan Protokol covid-19 (9 item APD);

Dalam upaya pencegahan TPS sebagai cluster penyebaran Covid 19 adalah dengan melakukan hal-hal sebagai berikut:

1) Jumlah Pemilih Untuk Setiap TPS Pada Penyelenggaraan Pemilihan Lanjutan Dalam Kondisi Bencana Nonalam Covid-19 Paling Banyak 500 (Lima Ratus) Orang agar tidak berdesak-desakan, dan setiap TPS dibuatkan protokol Covid 19;

2) Penyelenggara Pemilu yang bertugas menggunakan APD minimal masker, handsanitizer, pelindung wajah dan sarung tangan;

3) Pembuatan TPS dilakukan paling lama 1 (satu) hari sebelum hari pemungutan suara dan sebaiknya dilakukan penyemprotan disinfectan sesuai dengan standar protokol kesehatan pencegahan penyebaran Covid-19;

4) Jumlah Pemilih dalam lokasi TPS pada satu waktu paling banyak 12 (dua belas) Pemilih yang diatur sesuai dengan protokol kesehatan pencegahan penyebaran Covid-19 (Phisycal Distancing);

5) Tiap TPS disiapkan, thermogun, handsanitizer, air dan sabun cuci tangan di pintu masuk dan keluar TPS;

6) Saksi pasangan calon memakai masker dan sarung tangan;

7) Pemilih dengan suhu tubuh paling rendah $38^{\circ}$ (tiga puluh delapan derajat) Celsius dan/atau Pemilih yang terpapar Covid-19 pada saat pemungutan suara di TPS diberikan kesempatan untuk 
memberikan suara di tempat khusus di luar TPS sesuai dengan protokol kesehatan pencegahan penyebaran Covid-19;

8) Membatasi Jumlah Pemilih yg Berada di TPS dengan Mengatur Waktu Kedatangan (Sosial Distancing);

9) Saat Rekapitulasi cukup disaksikan petugas dan saksi sesuai dengan protokol kesehatan pencegahan penyebaran Covid-19;

\section{Mengoptimalkan Aturan Kampanye Di Media Masa Selama Covid 19}

Ditetapkannya PKPU No.6 Tahun 2020 tentang Pelaksanaan Pemilihan Kepala Daerah Serentak dalam kondisi bencana alam pandemi Covid 19, memunculkan beberapa hal baru dari segi metode kampanye bagi calon yang maju pada kontestasi 9 Desember 2020. Metode kampanye yang dilakukan oleh pasangan calon kepala daerah lebih menekankan kegiatan melalui media daring/online/virtual.

Munculnya norma baru terkait metode kampanye iklan kampanye di media daring pada peraturan KPU tersebut disebabkan Undang-Undang Pemilu No.7 Tahun 2017 tentang pemilu sudah memuat pengaturan metode kampanye secara daring. Terdapat aturannya dipasal 275 ayat 1 huruf f undangundang No.7 Tahun 2017 tentang pemilihan umum menyebutkan kampanye pemilu dapat dilakukan melalui iklan di media masa cetak, media masa elektronik dan internet.

Sedangkan sampai saat ini belum ada perubahan terhadap UU No,10 Tahun 2016 tentang pilkada. Menariknya bahwa pada pasal 62 ayat 2 PKPU No,6 Tahun 2020 menyatakan "penayangan iklan kampanye sebagaimna dimaksud pada ayat 1 dapat dilaksanakan selama masa kampanye. Berbeda perlakuannya pada iklan kampanye di media cetak dan media massa elektronik yang ditentukan waktunya, sementara penayangan iklan kampanye di media daring tidak terdapat pengaturan waktunya. Pilkada tahun ini pasangan calon kepala daerah dapat memasang iklan di media daring/online dari awal masa kampanye dan berakhir sampai dimulianya masa tenang.

Terjadi pergeseran pola kampanye bila pilkada dilaksanakan di masa pandemi virus (Vovid 19) seperti saat ini, kampanye sekarang tidak lagi ada yang disebut dengan kumpul-kumpul. Ini yang disebut dengan teori kinunikasi dengan peradaban layar. Para calon harus bisa mengoptimalkan media sosial sebagai sarana kampanye, pada calon harus membentuk tim kreatif yang ahli mengelola media sosial.

Mengoptimalkan kampanye di media sosial, perang tagar atau trending topic di twiter, siaran langsung di facebook, atau membuat akun youtube, itu yang disebut dengan peradaban layar yang ditentukan oleh tim kreatif para tim sukses. Para calon harus bisa membuat slogan, kalimat kampanye yang menarik untuk diunggah di media sosial. Slogan yang dibuat itu harus bisa membentuk opini publik. Kalau sudah menjadi opini publik ini akan menjadi keuntungan. Opini publik harus memiliki isu sentral, di masa pandemi para calon harus pandai dan cerdas dalam mengoptimalkan kampanye di media sosial sepanjang tidak ada saling mencermakan nama baik, hoaks, ujaran kebencian, dan saling mencari kesalahan antara satu dengan yang lain (berkampanye dengan santun).

Komisi Pemilihan Umum memberikan kesempatan luas kepada pasangan calon pilkada 2020 untuk memanfaatkan sosial media sebagai medium kampanye. Cara itu dinilai bisa menjadi solusi di pembatasan pertemuan tatap muka akibat pandemi Covid 19. Media daring sejak hari pertama sampai dengan menjelang pemungutan suara dapat dilakukan oleh pasangan calon.

Jika mengacu PKPU 5/2020 tentang tahapan, program dan jadwal masa kampanye berlangsung sejak 26 September hingga masa masa tenang yang jatuh pada 6 Desember 2020. Dengan demikian, kampanye media sosial dapat dilakukan 71 hari. Jadi sepenuh waktu, berbeda dengan media cetak, media elektronik dan seterusnya. Dalam PKPU 5/2020 durasi kampanye dimedia masa baik cetak, online maupun elektronik, membatasi selama 14 hari yang diluai pada 22 November dan berakhir 5 Desember atau 14 hari. 
Ruang kampanye daring yang luas diharapkan bisa mengisi berkurangnya tatap muka. Kampanye bukan hanya untuk kepentingan calon, namun juga kebutuhan bagi pemilih. Disadari memang kesemaraan kampanye pada pilkada 2020 berpotensi akan berlangsung tidak merata. Pasalnya, ketentuan kampanye terbuka akan disesuaikan dengan kondisi penyebaran Covid 19 atau berdasarkan zonasi.

Hal itu sebagaimana tertuang pada Peraturan KPU Nomor 6 Tahun 2020. Dalam pasal 64 ayat 1 disebutkan rapat umum terbuka digelar secara virtual. Kemudian pada ayat 2 dijelaskan dalam hal tidak digelar virtual, salah satu syarat yang harus dipenuhi adalah wilayah setempat bebas dari persebaran virus Covid 19. Itu pun dengan protokol yang ketat seperti berjarak 1 meter antar peserta dan kapasitas dibatasi 50 persen.

Kepastian daerah bebas dari persebaran Covid-19 harus dikeluarkan oleh Gugus Tugas. Untuk itu, dalam pasal 64 ayat 3 disebutkan, KPU daerah harus berkoordinasi dengan gugus tugas dalam menentukan pelaksanaan kampanye terbuka. Karena KPU tidak bisa menilai daerah tersebut masih kategori zona yang mana boleh melaksanakn kampanye.

\section{Melibatkan Seluruh Komponen Masyarakat Untuk Meningkatkan Partisipasi Pemilih}

Tingkat kehadiran pemilih ke TPS bukanlah satu-satunya hal yang menunjukkan partisipasi masyarakat, ada banyak hal yang bisa dilakukan oleh masyarakat guna berpartisiapasi dalam pilkada diantara menghadiri kampanye, menjadi pemantau, menjadi penyelenggara pilkada ataupun menjadi peserta pilkada. Tetapi secara kuantitatif parameter keberhasilan pilkada dapat dilihat dari jumlah pemilih yang memberikan hak pilih dalam pilkada yang mewujudkan tingkat partisipasi masyarakat. Semakin tinggi presentase tingkat kehadiran pemilih yang menggunakan hak pilih, semakin berhasil pelaksanaan pilkada, begitu juga sebaliknya.

Dari temuan banyak kasus seseorang tidak menggunakan hak pilihnya pada hari pencoblosan pemilih sedang sakit, ada kegiatan lain, ada di luar daerah, yang kesemuanya tidak sempat urus surat pindah memilih, pekerjaan sehari-hari yang memaksa pemilih untuk tidak hadir di TPS juga menjadi faktor teknis sehingga menghalanginya untuk menggunakan hak pilihnya.

Selain itu tidak punya pilihan dari kandidat yang tersedia atau tidak percaya bahwa pilkada akan membawa perubahan dan perbaikan, ketidakpercayaan dengan peserta pilkada serta beredarnya kepala daerah yang terjerat korupsi memungkinkan masyarakat untuk tidak menggunakan hak pilihnya. Kemudian, rentetan jadwal pemilu dan pemilihan yang berhimpitan mulai pilkada 2015, 2017, 2018, pemilu 2019 dikuatirkan juga menimbulkan kejenuhan yang berakibat mengurangi keinginan untuk datang ke TPS.

Tugas berat bagi KPU Provinsi dan KPU Kabupaten Kota di Sumatera Barat untuk mempertahankan atau bahkan meningkatkan tingkat partispasi masyarakat di angka 82,15 persen. Untuk mewujudkan hal itu maka KPU provinsi dan KPU kabupaten kota harus bisa menyadarkan dan menggandeng semua elemen yang terlibat dalam pemilihan kepala daerah, tugas untuk mempertahankan persentase partisipasi masyarakat atau bahkan meningkatkan partisipasi masyarakat bukan hanya tugas KPU saja, tetapi juga tugas pemerintah daerah, bawaslu, partai politik, pasangan calon dan masih banyak lagi stakeholders yang harus bahu membahu melaksanakan tugas tersebut.

Imbauan dari kami penyelenggara adalah luangkan waktu untuk memilih demi kamajuan daerah Sumatera barat dan tidak lupa untuk tetap mengedepankan protokol kesehatan demi mencegah penyebaran covid 19, agar demokrasi dan pemerintah tetap berjalan, sementara keamanan dan keselamatan rakyat tetap terlindungi 


\section{KESIMPULAN}

Salah satu parameter demokrasi lokal adalah melakukan pemilihan kepala daerah secara demokratis. Mencapai tujuan demokratis itu perlunya penyelenggaraan pilkada yang aman, terkendali dan tidak menimbulkan mara bahaya dari setiap tahapannya. Oleh karena itu penyelenggara KPU Provinsi Sumatera Barat berusaha untuk meujudkannya. Permasalahan yang terjadi pada lanjutan pilkada serentak tahun 2020 ini adalah KPU Provinsi Sumatera Barat dihadapkan pada situasi yang tidak normal akibat dari adanya kasus korona (Covid 19).

Sebagai penyelenggara KPU Provinsi Sumatera Barat mengacu pada Perpu Nomor 2 tahun 2020, PKPU Nomor 6 Tahun 2020 Tentang Pelaksanaan Pemilihan Gubernur dan Wakil Gubernur Atau Walikota dan Wakil Walikota Serentak Lanjutan Dalam Kondisi Bencana Nona Alam Corona Viris Disease 2019 (Covid 19) dan PKPU Nomor 5 Tahun 2020 Tentang Tahapan, Program dan Jadwal Penyelenggraan Pemilihan Gubernur, Bupati, Dan Atau Walikota dan Wakil Walikota Tahun 2020.

Dalam temuan peneliti di lapangan adapun strategi yang digunakan KPU Provinsi Sumatera Barat dalam menghadapi penundaan pilkada serentak di masa Pandemi Covid 19: meninjau update (terkini) perkembangan peta sebaran covid 19 Di Sumatera Barat, memastikan semua tahapan pilkada harus mematuhi protokol kesehatan, mengoptimalkan aturan kampanye di media masa selama Covid 19 dan melibatkan seluruh komponen masyarakat untuk meningkatkan partisipasi Pemilih.

\section{SARAN}

Adapun saran dalam penelitian ini adalah:

1. Sebagai penyelenggara di KPU Provinsi Sumatera Barat harus selalu mengedepankan kewaspadaan dan kehati-hatian dalam pilkada serentak pada segala aspek tahapan pemilu. Sebab masih banyak masalah yang ditemukan di lapangan menyangkut persoalan rawan dan berisikonya pilkada pada saat pandemi.

2. Masyarakat perlu terus meningkatkan pengetahuannya (melek politik) pada pilkada ini, semoga tidak terdorong untuk terlibat praktik money politic. Dengan edukasi politik yang dilakukan KPU Provinsi Sumatera Barat dan keterlibatan semua stakeholder semoga bisa meningkatkan partisipasi pemilih, apalagi pada saat pandemi kandidat/calon kepala daerah rentan menggunakan politik uang pada kondisi ekonomi warga yang lagi terdampak sejak Covid 19.

\section{DAFTAR PUSTAKA}

[1] Agustino, L. (2009). Pilkada dan Dinamika Politik Lokal (Cetakan I). Yogyakarta: Pustaka Pelajar.

[2] Amiruddin dan A Azaini Bisri. (2006). Pilkada Langsung, Problem, dan Propek. Jakarta: Pustidata Pelajar.

[3] Debora Sanur Lindawati. (2013). Strategi Politik dalam Menghadapi Pemilu 2014. Politica, 4(2), 289.

[4] Djormansyah Djohan, M. S. (2005). Pilkada Langsung Dan Peraturan. Jakarta: IIP Press.

[5] Harahap, A. A. (2005). Manajemen \& Resolusi Konflik Pilkada (1st ed.). Jakarta: PT Pustaka Cisendo. 
[6] https:m.tribunnews.com/amp/nasional/2020/01/16/ssimak-jadwal-dan-tahapan-pilkada-serentak-(n.d.).

[7] Idil Akbar. (2016). Pilkada Serentak Dan Geligat Dinamika Politik Dan Pemerintah Lokal Indonesua. Cocmogov Jurnal Ilmu Pemerintahan, 2(1), 1.

[8] Labolo, M. (2015). Menimbang Kembali Alternatif Mekanisme Pemilihan Kepala Daerah Di Indonesia. Administrasi Daerah, VIII(2), 1-2.

[9] Lisma, L. T. (2017). Implikasi Partisipasi Masyarakat Pada Pilkada serentak Dalam Meningkatkan Demokrasi Konstitusional Di Indonesia (Studi Terhadap Pelaksanaan Pilkada Serentak Di Provinsi Sulawesi selatan Tahun 2015). Jurnal Law Reform, 13(1), 1-12.

[10] Nopyandri. (2011). Pemilihan Kepala Daerah Yang Demokratiss Dalam Prespektif UUD 1945. Jurnal Ilmu Hukum, 2(2), 2.

[11] Nur Hidayah, dkk. (2014). Strategi Pemberdayaan Perempuan Di Panggak Darat Kecamatan Lingga Kabupaten Lingga. JUAN, 2(2), 3.

[12] Oliver, S. (2007). Strategi Publik Relations. Jakarta: Erlangga.

[13] Ridho Imawan Hanafi. (2014). Pemilihan Langsung Kepala Daerah Di Indonesia: Beberapa Catatan Kritis Untuk Partai Politik. Jurnal Penelitian Politik, 11(2), 1-16.

[14] Robert Dahl. (2001). Prilaku Demokrasi. Jakarta: Yayasan Obor Indonesia.

[15] Sugiono. (2014a). Metode Penelitian Kuantitatif, Kualitatif, Dan R\&D. Edisi Kedua puluh satu. Bandung: Alfabeta.

[16] Tangkilisan, H. N. (2009). Kebijakan Publik Yang Membumi. Yogyakarta: Lukman Offset dan Yayasan Pembaharuan Administrasi Publik Indonesia. 